
\title{
S.
}

Prepared in cooperation with the San Antonio Water System

\section{Borehole Geophysical, Fluid, and Hydraulic Properties Within and Near the Freshwater/Saline-Water Transition Zone, San Antonio Segment of the Edwards Aquifer, South-Central Texas, 2010-11}

\section{Introduction}

The freshwater zone of the San Antonio segment of the Edwards aquifer is used by residents of San Antonio and numerous other rapidly growing communities in south-central Texas as their primary water supply source (fig. 1). This freshwater zone is bounded to the south and southeast by a saline-water zone with an intermediate zone transitioning from freshwater to saline water (transition zone). As demands on this water supply increase, there is concern that the transition zone could potentially move, resulting in more saline water in current freshwater supply wells. Since 1985, the U.S. Geological Survey (USGS), San Antonio Water System (SAWS), and other Federal and State agencies have conducted studies to better understand the transition zone.

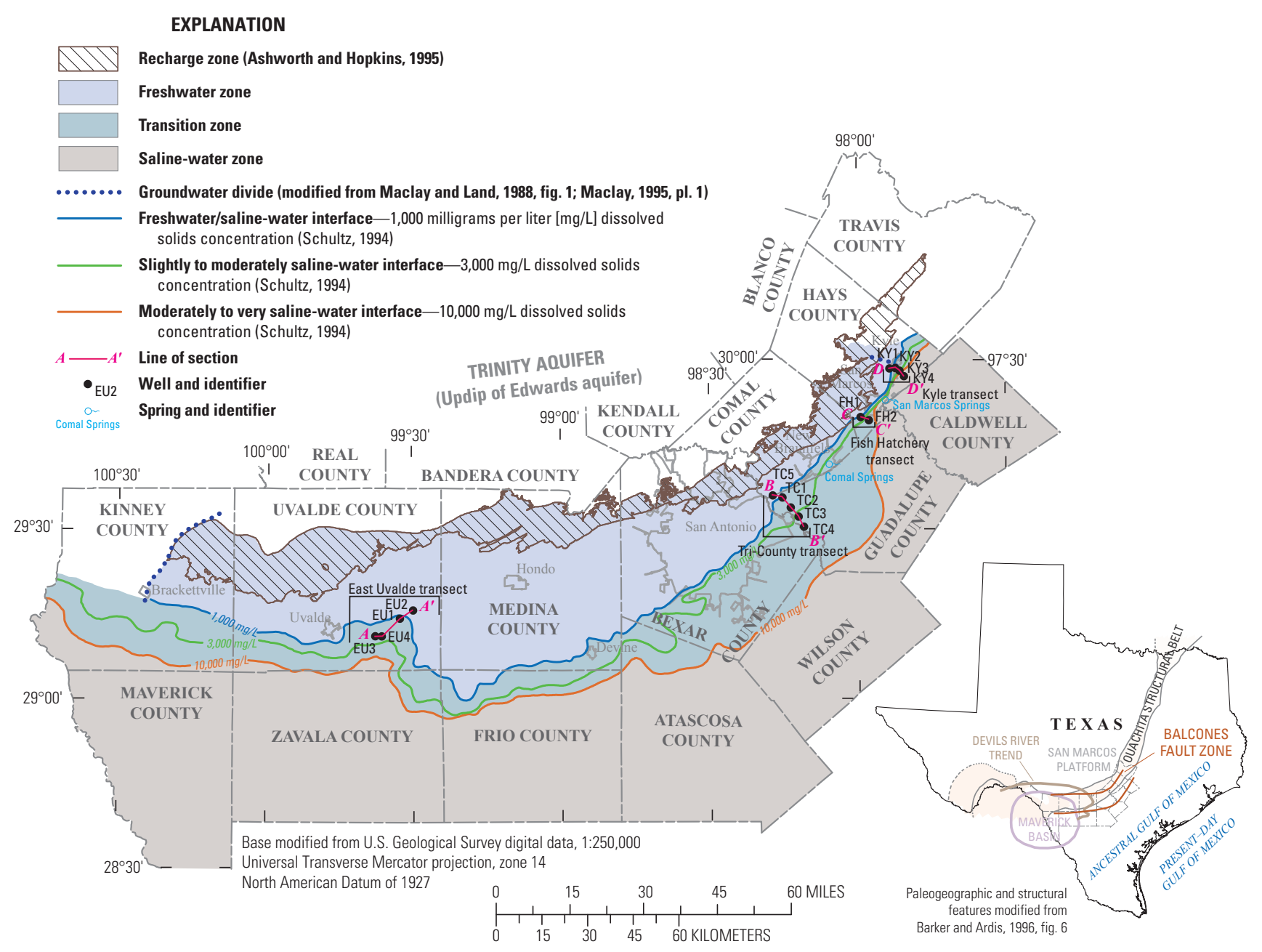

Figure 1. Areal extent of the freshwater/saline-water transition zone of the San Antonio segment of the Edwards aquifer, south-central Texas, and locations of monitoring wells within and near the transition zone from which data were collected for this report, 2010-11 (modified from Lambert and others, 2010, fig. 1). 
During 2010 and 2011, the USGS, in cooperation with SAWS, conducted a study to further assess the potential for movement of the transition zone in part of the San Antonio segment of the Edwards aquifer (Thomas and others, 2012; fig. 1). Equivalent freshwater heads were computed to investigate the transition from freshwater to saline-water zones in the San Antonio segment and evaluate the potential for lateral flow at the freshwater/saline-water interface. Data were collected within and near the transition zone from 15 monitoring wells in four transects (East Uvalde, Tri-County, Fish Hatchery, and Kyle; fig. 1).

\section{Hydrogeologic Setting}

The San Antonio segment of the Edwards aquifer (the study area) is about 175 miles long and extends from the western groundwater divide near Brackettville in Kinney County to the eastern groundwater divide near Kyle in Hays County (fig. 1). From its outcrop (recharge zone), the Edwards aquifer dips to the southeast at about 300-400 feet per mile and becomes buried and confined toward the present-day Gulf of Mexico coastline. From its outcrop immediately north of the Edwards aquifer recharge zone, the Trinity aquifer dips to the southeast beneath the Edwards aquifer, thus forming the northern lateral boundary and the underlying boundary of the Edwards aquifer.

The present-day Edwards aquifer formed along a crustal zone of weakness known as the Ouachita structural belt (Maclay, 1995) and consists of Cretaceous-age carbonate rocks of varying lithologies that were deposited in three depositional environments, or depositional provinces: the Maverick Basin, the Devils River Trend, and the San Marcos Platform (fig. 1). These depositional environments in part influence the transmissive and storage properties of the aquifer.

The direction of groundwater flow is controlled partially by regional faulting (Maclay and Land, 1988). Once in the aquifer, groundwater generally moves downdip and then is directed by faults to the east and northeast toward Comal Springs and San Marcos Springs, major springs in the northeastern part of the San Antonio segment of the aquifer (fig. 1; Groschen, 1994; Maclay, 1995).

\section{Description of Transects and Monitoring Wells}

The monitoring wells that provided data for this report were drilled during 1997-2001 by SAWS. The four transects (East Uvalde, Tri-County, Fish Hatchery, and Kyle; fig. 1) consist of 2-5 wells per transect and were configured approximately perpendicular to and across the expected trace of the freshwater/saline-water interface. A well descriptor was applied to each well on the basis of water type in the borehole (freshwater, saline water, or interface [freshwater atop saline water]; fig. 2).

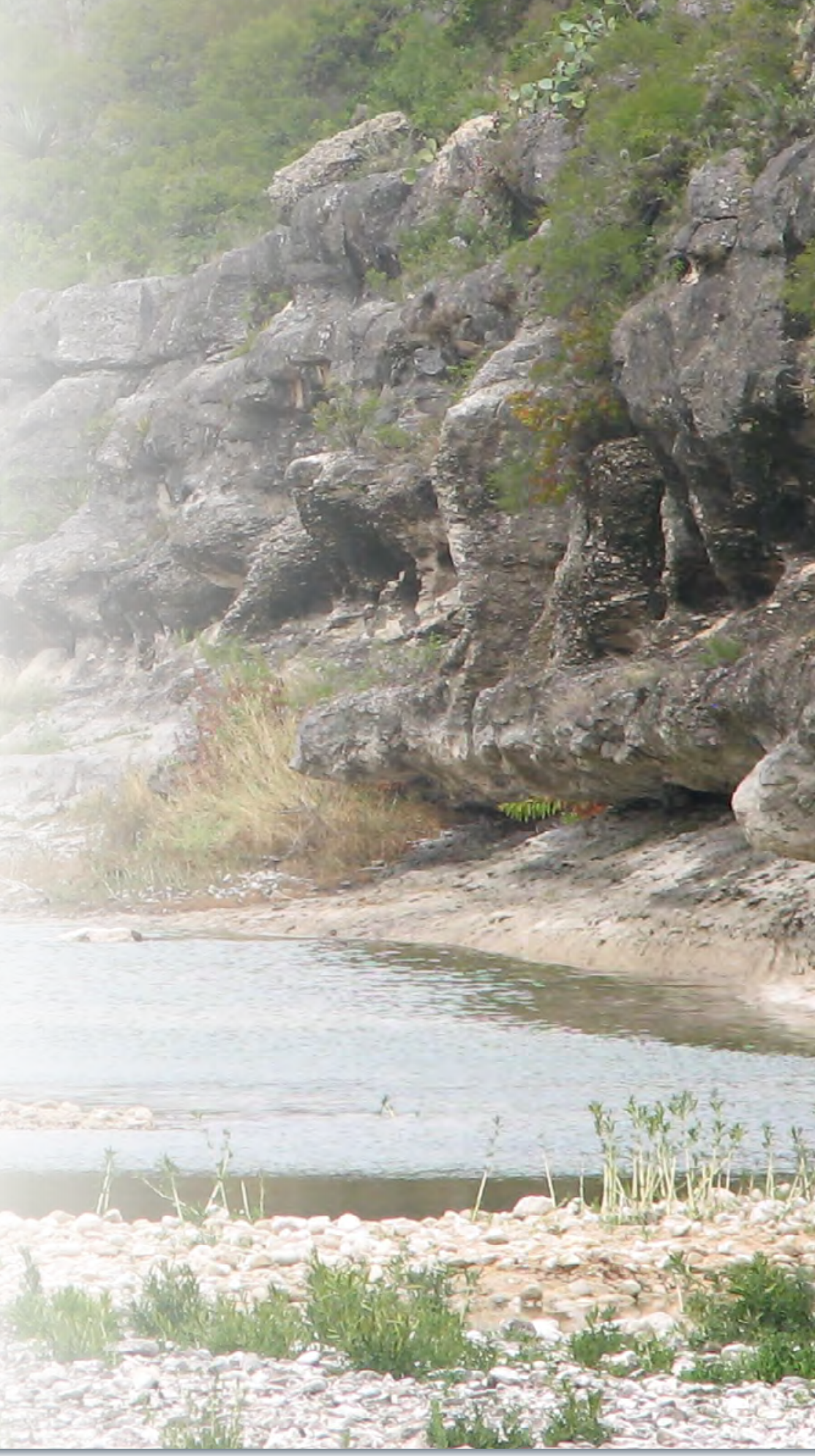



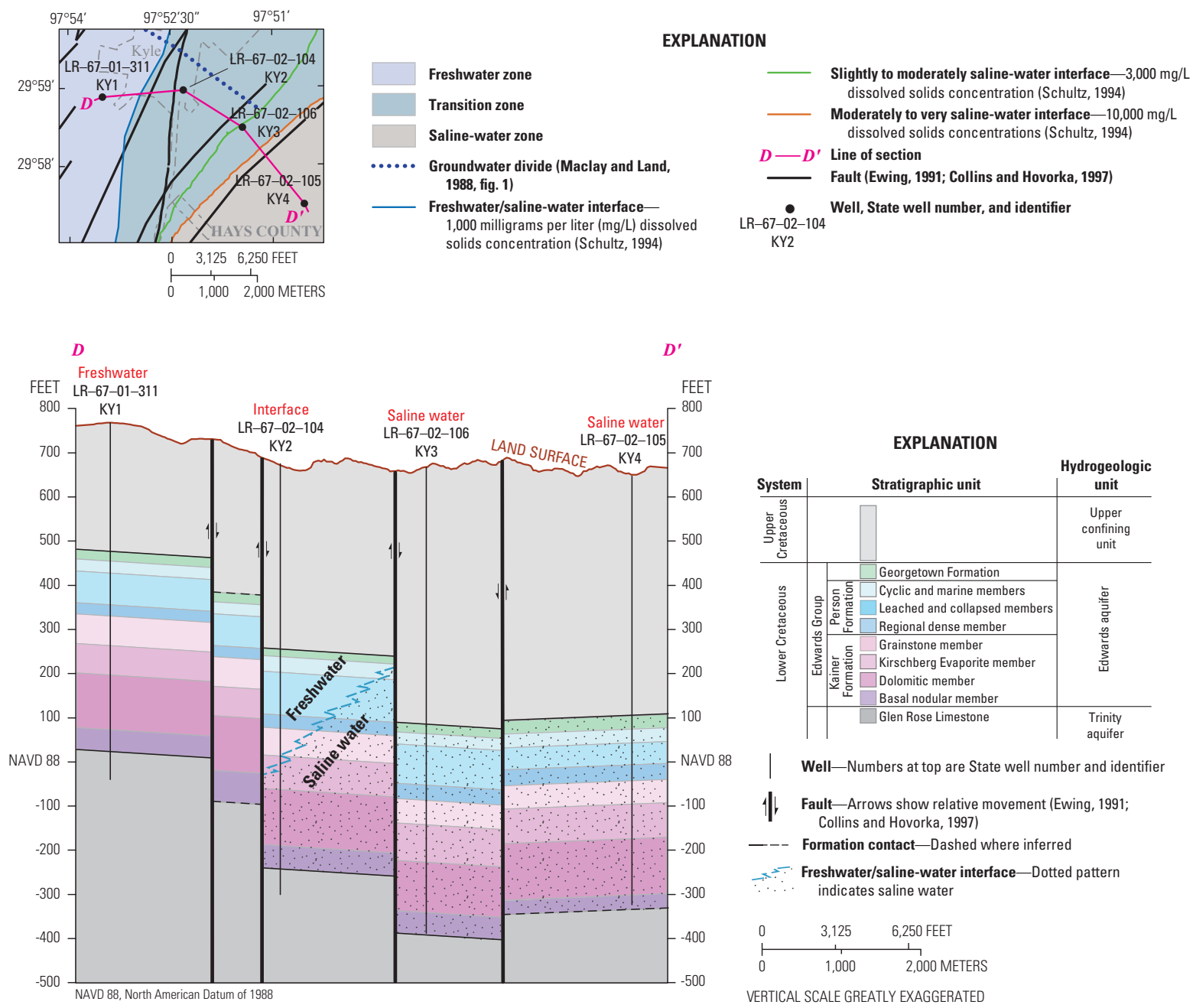

Figure 2. Hydrogeologic section of the Kyle transect $(D-D)$, San Antonio segment of the Edwards aquifer, south-central Texas (modified from Lambert and others, 2010, fig. 8).

\section{Borehole Geophysical, Fluid, and Hydraulic Properties}

Borehole geophysical data such as natural gamma, formation resistivity, and caliper are commonly used to characterize and identify stratigraphic units. These data were collected by the USGS at all 15 transect wells in the study area during a previous study (Lambert and others, 2009) and utilized to determine the stratigraphy of each well. Optical and acoustic televiewer logs were also collected and used to confirm the tops and bases of hydrostratigraphic subdivisions and assess voids and faulting identified in the rocks intersecting each well (fig. 3 ). In 2010, to further assess the potential for movement of the transition zone, electromagnetic (EM) flowmeter and multiparameter fluid $\log$ s that directly measured specific conductance and temperature were collected from 13 transect wells. The EM flowmeter logs were collected under ambient (nonpumping) and stressed (pumping) hydraulic conditions to assess the hydraulics of flow within the aquifer. Water-level data provided hydraulic-head data that were used to interpret borehole geophysical data.
Fluid property logs were used as indicators of possible flow zones, as calculations of equivalent freshwater head, and as a characterization of the borehole fluid. Borehole fluid was classified on the basis of total dissolved solids (TDS) concentration. To correlate specific-conductance values with TDS concentrations, observations of specific conductance and TDS concentration from Lambert and others (2009) were related by regression to yield threshold values of specific conductance corresponding to the threshold values of TDS concentrations that describe freshwater and categories of saline water (slightly, moderately, or very saline; fig. 4).

Changes between ambient and stressed calculated specific-conductance logs were analyzed to identify possible vertical or horizontal flow zones, to identify direction of flow, and to establish the relation between the ambient water in the borehole and the formation water entering the borehole during pumping. Flow-Log Analysis of Single Holes (FLASH) is a spreadsheet-based graphical user interface that supplies multilayered Thiem modeling results for steady-state flow of a borehole (Day-Lewis and 


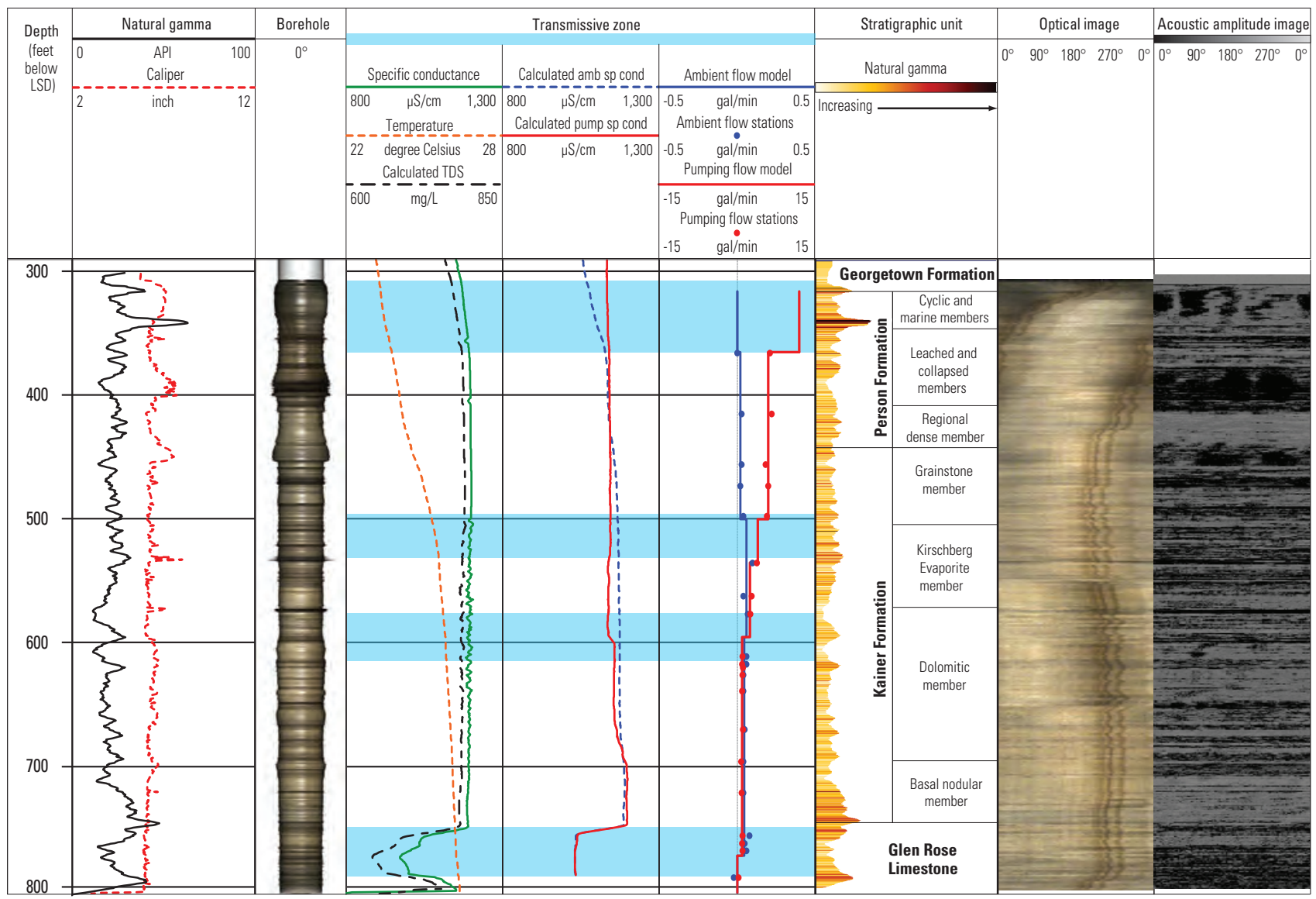

API, American Petroleum Institute; mg/L, milligrams per liter; $\mu \mathrm{S} / \mathrm{cm}$, microsiemens per centimeter; gal/min, gallons per minute; TDS, total dissolved solids; Calculated amb sp cond, Specific conductance logs calculated from fluid resistivity logs collected with the electromagnetic (EM) flowmeter probe under ambient conditions; Calculated pump sp cond, Specific conductance logs calculated from fluid resistivity logs collected with the EM flowmeter probe under pumped conditions; Calculated TDS, estimated total dissolved solids profile calculated from the specific conductance log; LSD, land-surface datum referenced to the North American Vertical Datum of $1988 ;^{\circ}$, degree.

Figure 3. Selected borehole geophysical data from Kyle transect well KY2 (LR-67-02-104), San Antonio segment of the Edwards aquifer, southcentral Texas, 2003-10 (modified from Thomas and others, 2012, fig. 19).
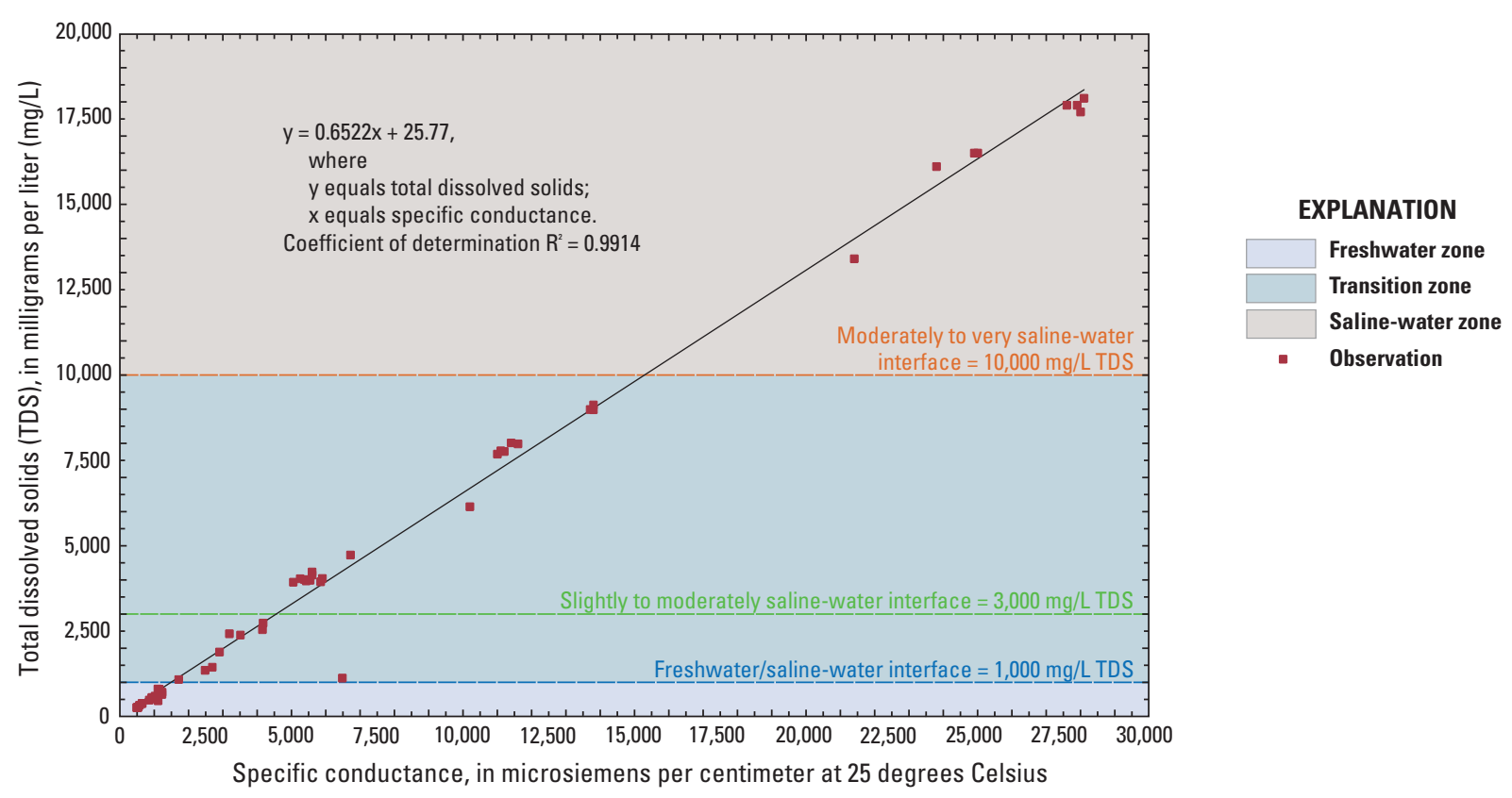

Figure 4. Observations of specific conductance and total dissolved solids (TDS) concentration related by regression to yield threshold values of specific conductance corresponding to the threshold values of TDS concentrations that describe freshwater and categories of saline water (slightly, moderately, or very saline),1999-2007 (modified from Thomas and others, 2012, app. 2). 
others, 2011). FLASH modeling results provided estimates of the differences between the open-hole water level under ambient and stressed conditions, transmissivities, and hydraulic heads for two or more water-producing (flow) zones intersecting a single borehole.

\section{Hydraulics of Lateral Flow}

Hydraulic heads in the aquifer primarily change in response to changes in recharge from rainfall and changes in nearby groundwater pumping. In karst systems such as the Edwards aquifer, changes in hydraulic heads can be abrupt, prolonged, or both (Wong and others, 2012). These changes in hydraulic heads were assessed to indicate to what extent transect wells were hydraulically connected to each other.

Equivalent freshwater heads define hydraulic gradients horizontally, and environmental-water heads define hydraulic gradients vertically (Lusczynski, 1961). Changes in hydraulic heads were used to evaluate lateral-head gradients and thus the potential for movement of water from the saline zone into the freshwater zone (fig. 5). Because saline water is slightly denser than freshwater, higher salinity of water causes a greater difference between the environmental-water head relative to the equivalent freshwater head. This correction was then used to convert measured water-level altitudes to equivalent freshwater-head altitudes. The direction of lateral-head gradients across the freshwater/saline-water interface was used to evaluate the potential for lateral flow across the freshwater/saline-water interface relative to the freshwater zone in the East Uvalde, Tri-County, and Kyle transects (into the freshwater zone, out of the freshwater zone, or mixed with regard to direction [head higher or lower at the freshwater/saline-water interface than on either side]). Lateral-head gradients were not computed for the Fish Hatchery transect because of the relatively large difference in altitude between the open-hole sections of wells FH1 and FH2, caused by fault offset, and the relative shallowness of well FH1.
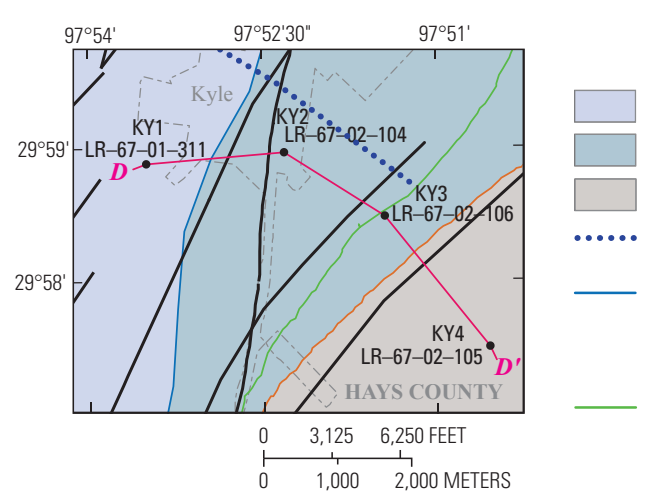

Freshwater zone

Transition zone

Saline-water zone

Groundwater divide (Maclay and Land, 1988, fig. 1)

Freshwater/saline-water interface1,000 milligrams per liter ( $\mathrm{mg} / \mathrm{L}$ ) dissolved solids concentration (Schultz, 1994)

Slightly to moderately saline-water interface$3,000 \mathrm{mg} / \mathrm{L}$ dissolved solids concentration (Schultz, 1994)

\section{EXPLANATION}

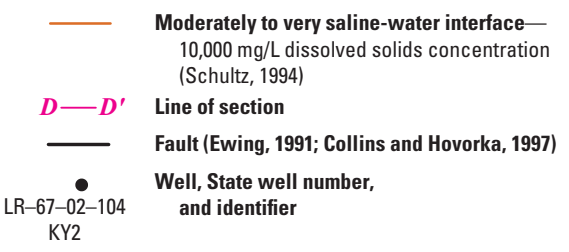

EXPLANATION
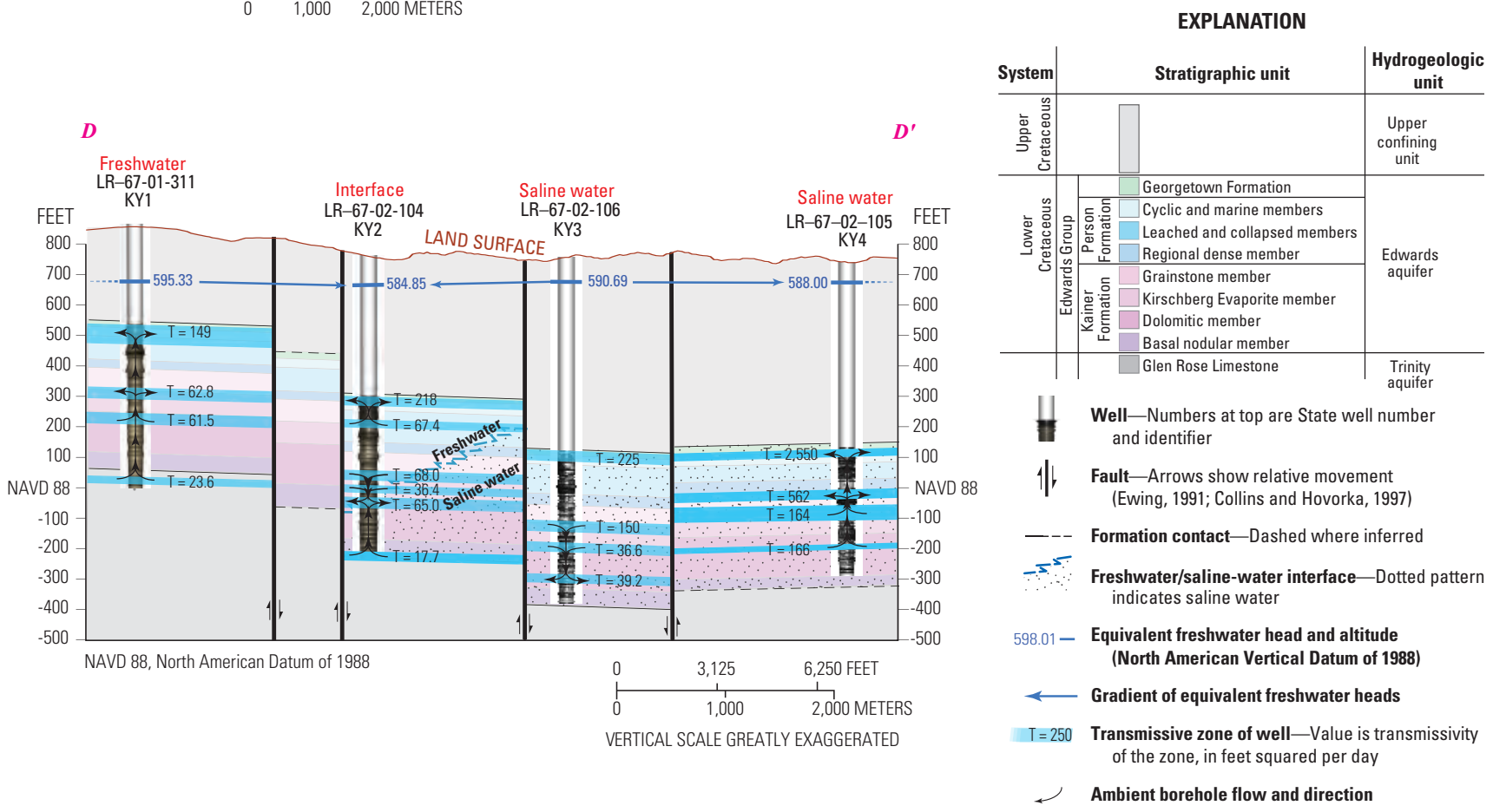

Figure 5. Conceptual diagram showing ambient flow, transmissive zones, and equivalent freshwater heads in monitoring wells in the Kyle transect, San Antonio segment of the Edwards aquifer, south-central Texas, 2010 (modified from Thomas and others, 2012, fig. 26). 


\section{This fact sheet is based on Thomas and others, 2012.}

\section{References}

Ashworth, J.B., and Hopkins, Janie, 1995, Aquifers of Texas: Texas Water Development Board Report 345, 69 p.

Barker, R.A., and Ardis, A.F., 1996, Hydrogeologic framework of the Edwards-Trinity aquifer system, west-central Texas: U.S. Geological Survey Professional Paper 1421-B, 61 p.

Collins, E.W., and Hovorka, S.D., 1997, Structure map of the San Antonio segment of the Edwards aquifer and Balcones fault zone, south-central Texas - Structural framework of a major limestone aquifer, Kinney, Uvalde, Medina, Bexar, Comal, and Hays Counties: Austin, The University of Texas, Bureau of Economic Geology Miscellaneous Map 38, scale 1:250,000.

Day-Lewis, F.D., Johnson, C.D., Paillet, F.L., and Halford, K.J., 2011: A computer program for flow-log analysis of single holes (FLASH): Ground Water, v. 49, no. 6, p. 926-931, accessed December 8, 2012, at http://onlinelibrary.wiley.com/doi/10.1111/j.17456584.2011.00798.x/pdf.

Ewing, T.E., 1991, The tectonic framework of Texas-The tectonic map of Texas: Austin, The University of Texas, Bureau of Economic Geology, 36 p.

Groschen, G.E., 1994, Analysis of data from test-well sites along the downdip limit of freshwater in the Edwards aquifer, San Antonio, Texas, 1985-87: U.S. Geological Survey Water-Resources Investigations Report 93-4100, 92 p.

Lambert, R.B., Hunt, A.G., Stanton, G.P., and Nyman, M.B., 2009, Water-level, borehole geophysical log, and water-quality data from wells transecting the freshwater/saline-water interface of the San Antonio segment of the Edwards aquifer, south-central Texas, 1999 2007: U.S. Geological Survey Data Series 403 [variously paged].

Lambert, R.B., Hunt, A.G., Stanton, G.P., and Nyman, M.B., 2010, Lithologic and physicochemical properties and hydraulics of flow in and near the freshwater/saline-water transition zone, San Antonio segment of the Edwards aquifer, south-central Texas, based on water-level and borehole geophysical log data, 1999-2007: U.S. Geological Survey Scientific Investigations Report 2010-5122, 69 p.
Lusczynski, N.J., 1961, Head and flow of groundwater of variable density: Journal of Geophysical Research, v. 66, no. 12 , p. 4247-4256.

Maclay, R.W., 1995, Geology and hydrology of the Edwards aquifer in the San Antonio area, Texas: U.S. Geological Survey WaterResources Investigations Report 95-4186, 64 p.

Maclay, R.W., and Land, L.F., 1988, Simulation of flow in the Edwards aquifer, San Antonio region, Texas, and refinement of storage and flow concepts: U.S. Geological Survey Water-Supply Paper 2336-A, 48 p.

Schultz, A.L., 1994, Review and update of the position of the Edwards aquifer freshwater/saline-water interface from Uvalde to Kyle, Texas: Edwards Underground Water District Report 94-05, $31 \mathrm{p}$.

Thomas, J.V., Stanton, G.P., and Lambert, R.B., 2012, Borehole geophysical, fluid, and hydraulic properties within and surrounding the freshwater/saline-water transition zone, San Antonio segment of the Edwards aquifer, south-central Texas, 2010-11: U.S. Geological Survey Scientific Investigations Report 2012-5285, 65 p., 3 apps., http://pubs.usgs.gov/sir/2012/5285/.

Wong, C.I., Mahler, B.J., Musgrove, M., and Banner, J.L., 2012, Changes in sources and storage in a karst aquifer during a transition from drought to wet conditions: Journal of Hydrology, v. 468-469, p. 159-172

\section{-By Jonathan V. Thomas and Gregory P. Stanton}

\section{For additional information, contact}

Director, Texas Water Science Center

U.S. Geological Survey

1505 Ferguson Lane

Austin, Texas 78754-4501

http://tx.usgs.gov/ 